\title{
Filipino Generation Z on Mobile Legends during COVID-19: A Determination of Playtime and Satisfaction
}

\author{
Ryuichi T. Kishimoto, Yogi Tri Prasetyo, Satria Fadil Persada, and A. A. N. Perwira Redi
}

\begin{abstract}
The Filipinos are current in lockdown that is to prevent the spreading of COVID-19 in the country. In this paper, we are focusing in determining the playtime and satisfaction of Gen Z-ers which were born from 1997 onwards who plays Mobile Legends: Bang Bang. In this paper, we utilize the Structural Equation Modelling (SEM) and applying the Self-Affirmation Theory (SAT) for the research framework of this study. The researchers gathered 257 valid participants in which most of them were high school and college students. We will see in the result section the factor loadings of our model wherein we found out that the impact of self-worth to playtime has the largest patch coefficient. Surprisingly, we also found out that there is no significant effect in the self-worth to satisfaction. We also showed here that the model fits our data giving the result of index is within the suggested values $(\mathrm{GFI}=0.86, \mathrm{CFI}=$ 0.92, AGFI $=0.82$, TLI $=0.92$, IFI $=0.93$, RMSEA $=0.068$, CMIN/DF $=2.9$ ).
\end{abstract}

Index Terms-COVID -19, Esports, mobile legends, Esports satisfaction.

\section{INTRODUCTION}

In the Philippines, the community lockdown has implemented on March 15, 2020, due to the pandemic, COVID-19 [1]. According to the report of Department of Health $(\mathrm{DOH})$ there were total cases of 307, 288 which consist of 49, 242 active cases, 5, 381 reported deaths 252, 665 for total recoveries [2]. Still, the battle of the country against the COVID-19 is not yet over and hoping that it will flatten its curve soon.

While the government has its lockdown protocols wherein ages 20 below are still not allowed to go outside, these range of age falls under Generation Z. According to Pew Research Center, they defined those people who were born from 1997 as of these present times [3]. These individuals who are under Gen Z-ers are said to be more adaptable with the technologies that we have right now. As far as technology is a concern, we have smartphones nowadays wherein we can use it as part of our entertainment that is, we used it in gaming in which we tend to download different games on different platforms and play it for most of our leisure time.

Manuscript received January 13, 2021; revised May 7, 2021. This work was supported by the Mapúa University Directed Research for Innovation and Value Enhancement (DRIVE).

Ryuichi T. Kishimoto and Yogi Tri Prasetyo are with the School of Industrial Engineering and Engineering Management, Mapúa University, Philippines (e-mail: ryuichikishimoto04@gmail.com, ytprasetyo@mapua.edu.ph).

Satria Fadil Persada is with the Business Management Department, Institut Teknologi Sepuluh Nopember (ITS), Surabaya, Indonesia (e-mail: satriafp@gmail.com).

A. A. N. Perwira Redi is with Bina Nusantara University, Jakarta, Indonesia (e-mail: wira.redi@binus.edu).
Since smartphones have the features for gaming and it is very convenient to play due to its mobility that you can play anytime and anywhere so that many people are interested to play their games on their mobile phone. These mobile games become very popular in different parts of the world wherein in 2019, the mobile gamers reach 2.2 billion and it is also expected that in the year of 2023 the mobile gamers worldwide will reach up to 6.2 billion [4]. One of the most popular games in the Philippines which Filipinos are drawn to playing mobile game is the Mobile Legends: Bang Bang.

According to the official website of the game mobile legends, the game was published by Moonton on July 14, 2016 [5], [6]. The game set for this game is Multiplayer Online Battle Arena (MOBA) having a 5v5 which is the maximum number of members per team. While each member of the team will choose their heroes with their respective roles (tank, fighter, assassin, mage, marksman, support, and jungler), the players are going to battle with the other team to defeat their base in real-time gameplay [7]. This specific mobile game is considered as Esports wherein the game is being done with the use of technology particularly in computer and mobile phone.

Esports is already in the Southeast Asian Games (SEA). According to the report of $\mathrm{CNN}$, the Philippines won in Esports against Indonesia with the score of 3-2 and it is the first time they got a gold medal in this type of competition [8]. Through this event, we can say that Filipinos are now interested in playing mobile games and it is now considered as part of the sports that is, Esports.

Since Filipino Gen Z-ers are currently in lockdown, the tendency is that they will find their time to enjoy while in their houses. Therefore, the objective of this study is to determine the playtime and satisfaction of Filipino Generation $\mathrm{Z}$ during this pandemic utilizing the Structural Equation Modelling (SEM) applying the Self-Affirmation Theory (SAT) [9].

There are many studies regarding the playtime and satisfaction determination for online games [10] but there are no studies that focuses on a particular mobile game which is the Mobile Legends. To fill this gap, the researchers focuses on a particular game which is the Mobile Legends: Bang Bang. The researchers think that this study is also relevant in which Filipino Generation $\mathrm{Z}$ is in lockdown during this pandemic and soon the new mode of the class is approaching. This paper may contribute in shedding some light regarding the playtime and satisfaction of the mobile players of Filipino Gen Z-ers during this pandemic.

\section{Methodology}




\section{A. Data Collection}

Since this current time was almost all people were quarantined due to COVID-19 [11], [12], the researchres collected the data through an online survey. Using the Google forms which is very accessible to everyone to answer the questions provided by the researchers. To promote this survey, we posted the online survey with the help of social media platform sending them an invitation via personal message, different group chats, and group pages existing in the social media. As this study is all about people under generation $\mathrm{Z}$ who are playing mobile legends and they are currently playing during this pandemic, this is the qualification in order to acquire valid data for this study.

TABLE I: DEMOGRAPHIC PROFILE OF PARTICIPANTS

\begin{tabular}{|c|c|c|c|}
\hline Variable & Category & Number (N) & $\begin{array}{c}\text { Percentage } \\
(\%)\end{array}$ \\
\hline \multirow[t]{2}{*}{ Gender } & Male & 165 & 64.2 \\
\hline & Female & 92 & 35.8 \\
\hline \multirow[t]{4}{*}{ Age } & $8 \leq$ years $\leq 12$ & 1 & .4 \\
\hline & $13 \leq$ years $\leq 17$ & 108 & 42 \\
\hline & $18 \leq$ years $\leq 22$ & 137 & 53.3 \\
\hline & $23 \leq$ years $\leq 27$ & 11 & 4.3 \\
\hline \multirow[t]{4}{*}{ Education } & $\begin{array}{l}\text { High school } \\
\text { student }\end{array}$ & 35 & 13.6 \\
\hline & $\begin{array}{l}\text { Senior high school } \\
\text { student }\end{array}$ & 98 & 38.1 \\
\hline & $\begin{array}{l}\text { University/College } \\
\text { student }\end{array}$ & 104 & 40.5 \\
\hline & $\begin{array}{l}\text { University/College } \\
\text { Graduate }\end{array}$ & 20 & 7.8 \\
\hline Weekly & Less than 7 hours & 171 & 66.5 \\
\hline hours of & $7 \leq$ hours $\leq 14$ & 51 & 19.8 \\
\hline spent in & $15 \leq$ hours $\leq 21$ & 14 & 5.4 \\
\hline $\begin{array}{l}\text { playing } \\
\text { Mobile } \\
\text { Legends }\end{array}$ & 21 hours above & 21 & 8.2 \\
\hline Years of & Less than 1 year & 75 & 29.2 \\
\hline experience & $1 \leq$ years $\leq 2$ & 110 & 42.8 \\
\hline $\begin{array}{l}\text { in playing } \\
\text { Mobile } \\
\text { Legends }\end{array}$ & $3 \leq$ years $\leq 4$ & 72 & 28 \\
\hline
\end{tabular}

\section{B. Theoretical Framework}

The framework for this study is based on SAT (Self-Affirmation Theory) [9], [13]-[17]. According to the study of Sherman and Cohen, this theory says that an individual can be strongly motivated when it comes to maintaining its self-worth [4]. With the three basic needs that can be linked with the SAT theory namely; autonomy, competence, and relatedness which can be applied with the establishment of the framework with this study. See figure 2.1 for the research framework. The playtime and satisfaction [18], [19] add up to this framework in which we assess if this theory and the framework would explain the behavior of the current ML players during this pandemic.

\section{Hypothesis Development}

With the theoretical framework provided in this paper, here we applied the SAT theory to determine the playtime and satisfaction of every ML player based on the participants we gathered.

Autonomy may be defined as the capability of an individual to have freedom for decision making in a certain activity. In playing mobile legends, each member of the group will decide which role they will take part in before the starts. According to the study of Steele, the SAT theory may find that an individual affirms its self-worth if they can make their own choices [8]. Thus, the researchers hypothesized:

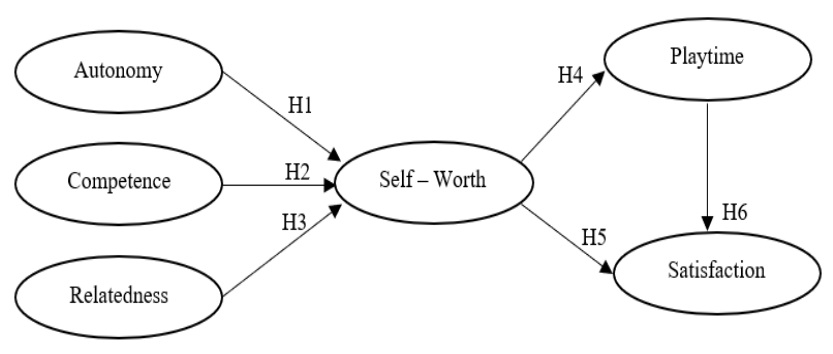

Fig. 1. Research framework.

H1: Autonomy is positively related to self-worth.

Competence here in this framework refers to the ability to do something successfully. With the statement of the paper presented on the previous researchers, it says that the competence would enhance its enjoyment and will lead to self-worth [9]. After the game in playing mobile legends, each player will the rewards based on the performance on that particular game. For example, a particular player got an award for the MVP while the rest got a Silver award. Thus, we hypothesized:

$\mathrm{H} 2$ : Competence is positively related to self-worth.

Relatedness refers to the social connections builds up while doing a particular within the group and these social connections said to be an important factor for self-affirmation [10]. There is a common feature for every mobile app game or in online games that are existing in these modern times, we have chat modes in which we connect ourselves though other players, and also there is a particular group message for the group players that are considered to be allied members. Thus, we hypothesized:

H3: Relatedness is positively related to self-worth.

Playtime refers to the time of gameplay of an individual where they are motivated to play i.e. playing mobile legends. In a study conducted by Alha in 2019, he said that having a good performance in gameplay will make an individual motivated to play online games. This can be also related to playing mobile legends in which if the players are winning in consecutive times there is a tendency that they will play more. Thus, we hypothesized:

$\mathrm{H} 4$ : Self - worth is positively related to playtime.

Also, if the players of mobile legends are in their momentum of winning streaks, it builds up the self-worth of an individual. Based on the framework that we've designed, we hypothesized:

H5: Self-worth is positively related to satisfaction.

Given the playtime of an individual in which they are motivated to play mobile legends. The researchers would also like to know if the playtime also affects the satisfaction of the player. Thus, we hypothesized:

H6: Playtime is positively related to satisfaction.

\section{Sample Profile}

The researchers gathered 257 valid mobile legends players under Generation Z. Most of them are males which were 165 
(64\%) participants and female of $92(35.8 \%)$ participants. The majority of our participants having a quantity of 137 $(53.3 \%)$ falls under the age of 18 to 22 years old. Also, we gathered 108 participants ages from 13 to 17 years old $(42 \%)$, 11 participants ages from 23 to 27 years of age $(4.3 \%)$, and one participant who has an age range from 8 to 12 years old. In education attainment of our participants, most of our participants were college/university students there were 104 (40.5\%). Also, the researchers gathered 98 (38.1\%) senior high school students, 35 (13.6\%) were high school students, and $20(7.8 \%)$ were already a college graduate. These participants also reported their hours of playing mobile legends in a week. Most of the participants which were 171 $(66.5 \%)$ reported that they are playing mobile legends below 7 hours of play per week. Also, there were $21(8.2 \%)$ of participants reported that they are playing mobile legends for more than 21 hours of play per week. Additionally, the years of experience of playing Mobile Legends were also reported. The majority of the participants were $110(42.8 \%)$ has an experience of 1 to 2 years in playing the said game and others reported were $72(28 \%)$ that they are playing for about 3 to 4 years. In table 4.1 shows the summary of the demographic profile of our participants.

\section{E. Questionnaire}

Through the research framework provided in this study, we developed a series of a self-administered questionnaire to determine the playtime and satisfaction of ML players during this pandemic. It consists of 7 sections: a) Personal Information of the ML players (age, gender, educational background, month /years of experience in playing ML, main role of player, and daily hours of play) b) Autonomy c) Competence d) Relatedness e) self - worth f) Playtime g) Satisfaction. A 5-point Likert scale was used by the researchers to measure the latent constructs included in our framework.

TABLE II: QUESTIONNAIRES FOR LATENT CONSTRUCTS

\begin{tabular}{|c|c|c|c|}
\hline Construct & Items & Measures & Source \\
\hline \multirow[t]{4}{*}{ Autonomy } & AU1 & $\begin{array}{l}\text { I feel that I can make my own } \\
\text { choice in choosing a hero. }\end{array}$ & $\begin{array}{l}\text { Chen et al } \\
\text { (2015) }\end{array}$ \\
\hline & AU2 & $\begin{array}{l}\text { I feel my choices express who I } \\
\text { really am. }\end{array}$ & \\
\hline & AU3 & $\begin{array}{l}\text { I feel my choice of position of } \\
\text { game (mid, bottom and top) } \\
\text { are right. }\end{array}$ & \\
\hline & AU4 & $\begin{array}{l}\text { I feel that my decisions reflect } \\
\text { what I really want. }\end{array}$ & \\
\hline \multirow[t]{4}{*}{ Competence } & $\mathrm{CO} 1$ & $\begin{array}{l}\text { I feel confident that I will win } \\
\text { in match. }\end{array}$ & $\begin{array}{l}\text { Chen et al } \\
\text { (2015) }\end{array}$ \\
\hline & $\mathrm{CO} 2$ & I feel capable at what I do. & \\
\hline & $\mathrm{CO} 3$ & $\begin{array}{l}\text { I feel I can successfully play } \\
\text { my role in match. }\end{array}$ & \\
\hline & $\mathrm{CO} 4$ & $\begin{array}{l}\text { I feel competent to achieve my } \\
\text { goals in the match. }\end{array}$ & \\
\hline \multirow[t]{4}{*}{ Relatedness } & RE1 & $\begin{array}{l}\text { I feel connected to my } \\
\text { teammate in playing ML. }\end{array}$ & $\begin{array}{l}\text { Chen et al } \\
(2015)\end{array}$ \\
\hline & RE2 & $\begin{array}{l}\text { I think I can feel connection } \\
\text { with other players while in } \\
\text { game }\end{array}$ & \\
\hline & RE3 & $\begin{array}{l}\text { I feel close and connected to } \\
\text { my friends in ML. }\end{array}$ & \\
\hline & RE4 & $\begin{array}{l}\text { I think I more motivated if my } \\
\text { friends invited me to play and } \\
\text { form as a group especially in } \\
\text { ranking match. }\end{array}$ & \\
\hline Self-Worth & SW1 & I feel worthiness while in & Liao (2019) \\
\hline
\end{tabular}

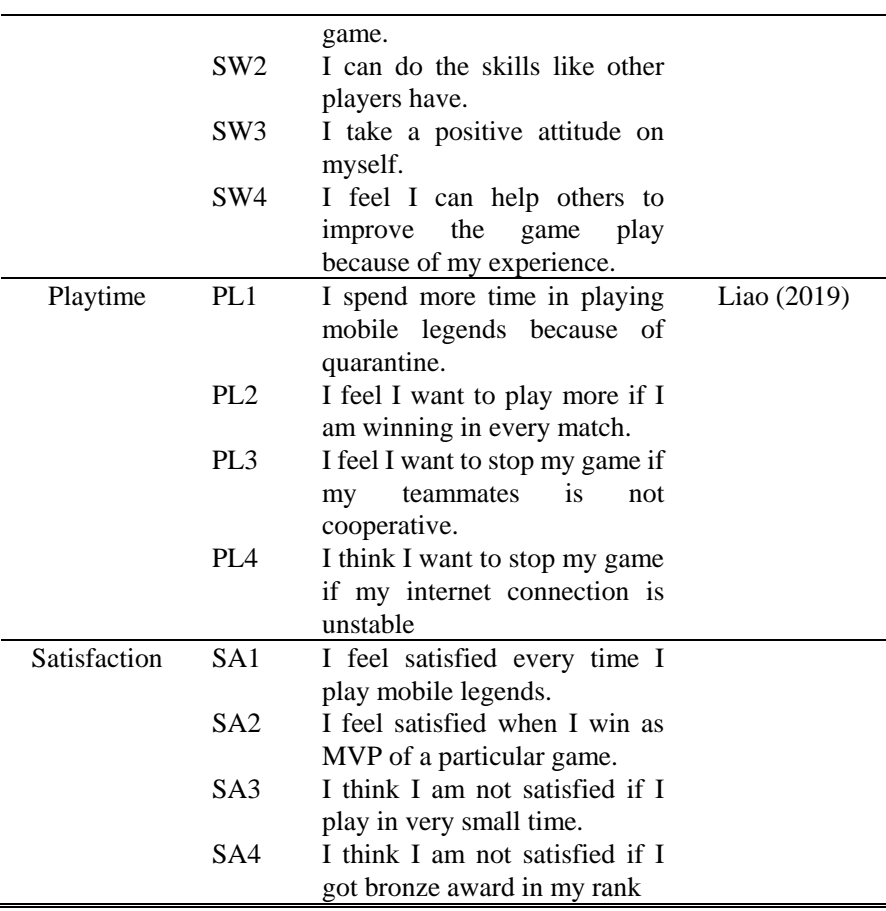

\section{F. Data Analysis}

The researchers were utilized the Structural Equation Modelling (SEM) using the AMOS 22 software to examine and estimate the maximum likelihood. To analyze our model fit with its validity and reliability, we used the confirmatory factor analysis with the following measurement indices namely: Comparative Factor Index (CFI), Adjusted Goodness of Fit Index (AGFI), Tucker Lewis Index (TLI), and Root Mean Square Error of Approximation (RMSEA).

\section{REsults}

Fig. 2 shows the SEM results for assessing the playtime and satisfaction in playing Mobile Legends during COVID-19. The hypothesis of this paper was analytically observed based on our participants who accessed our online survey. With the help of AMOS and SPSS software, we can determine the factor loadings, which is also determining the path coefficient $(\beta)$ to see the relationships of our model. Based on the figure, the path coefficients of our model show positively related to each other specifically in self-worth in which is positively related to playtime $(\beta=1.05, \mathrm{P}<0.001)$. While in autonomy, competence and relatedness are also positively related to self-worth respectively $(\beta=0.20,0.41$, 0.25 , and $p=0.007,0.001,0.001$ ). As we found out the impact of self-worth with playtime having a high impact relationship, self-worth does not significantly related to satisfaction. Additionally, the playtime has a positively effect to satisfaction $(\beta=0.66, \mathrm{P}<0.001)$. In table III shows the summary of factory loadings of our model. We also added the Cronbach's alpha that is to see the internal consistency of our measured constructs in which all values are greater than 0.70 which indicates good reliability. Table IV summarizes the path analysis of our SEM. Here, we can observe that all our paths with our latent variables are significant except with the relationship of self-worth to satisfaction. Furthermore, table $\mathrm{V}$ listed the model fit of our SEM. As we observed the given 
table, we can say that model fits our data $(\mathrm{GFI}=0.86, \mathrm{CFI}=$ $0.92, \mathrm{AGFI}=0.82, \mathrm{TLI}=0.92, \mathrm{IFI}=0.93, \mathrm{RMSEA}=0.068$, CMIN/DF $=2.9$ ).

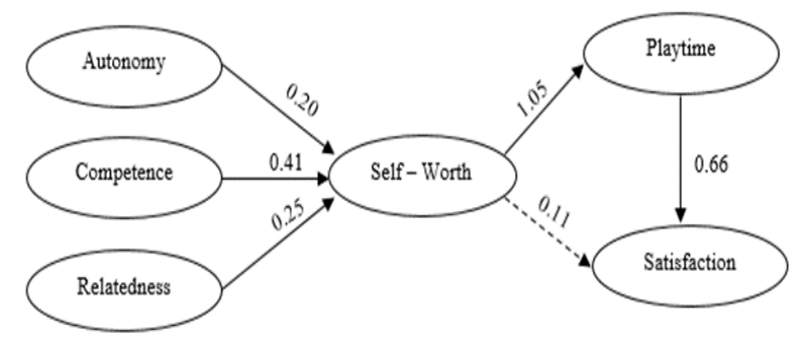

Fig. 2. Analytical Results of the model.

TABLE III: STATISTICAL DESCRIPTIVE RESULTS

\begin{tabular}{clcccc}
\multicolumn{6}{c}{ TABLE III: STATISTICAL DESCRIPTIVE RESULTS } \\
\hline \hline \multirow{6}{*}{ Factor } & Item & M & SD & $\propto$ & $\begin{array}{c}\text { Factor } \\
\text { Loading }\end{array}$ \\
\hline \multirow{5}{*}{ Autonomy } & AU1 & 3.58 & 0.97 & & 0.779 \\
& AU2 & 3.43 & 1.01 & 0.85 & 0.719 \\
& AU3 & 3.58 & 1.02 & & 0.824 \\
& AU4 & 3.49 & 1.00 & & 0.705 \\
& CO1 & 3.46 & 0.99 & & 0.795 \\
Competence & CO2 & 3.69 & 0.97 & 0.92 & 0.891 \\
& CO3 & 3.73 & 0.99 & & 0.875 \\
& CO4 & 3.68 & 0.99 & & 0.845 \\
Relatedness & RE1 & 3.35 & 1.01 & & 0.749 \\
& RE2 & 3.38 & 0.99 & 0.87 & 0.737 \\
& RE3 & 3.67 & 1.01 & & 0.803 \\
& RE4 & 3.84 & 1.06 & & 0.739 \\
Self-worth & SW1 & 3.34 & 0.95 & & 0.688 \\
& SW2 & 3.41 & 1.00 & 0.85 & 0.765 \\
& SW3 & 3.68 & 0.98 & & 0.748 \\
& SW4 & 3.54 & 0.96 & & 0.786 \\
& PL1 & 3.28 & 1.20 & & 0.706 \\
Playtime & PL2 & 3.74 & 1.05 & 0.78 & 0.802 \\
& PL3 & 3.56 & 1.17 & & 0.560 \\
& PL4 & 3.88 & 1.16 & & 0.596 \\
& SA1 & 3.44 & 0.89 & & 0.621 \\
& SA2 & 4.02 & 0.98 & 0.74 & 0.719 \\
& SA3 & 3.06 & 1.04 & & 0.489 \\
& SA4 & 3.43 & 1.17 & & 0.506 \\
\hline \hline
\end{tabular}

TABLE IV: PATH ANALYSIS FOR SEM

\begin{tabular}{lcccc}
\hline \multicolumn{1}{c}{ Hypothesis } & Estimate & S.E. & C.R. & P \\
\hline Autonomy $\rightarrow$ Self-worth & 0.203 & 0.076 & 2.683 & 0.007 \\
Competence $\rightarrow$ Self-worth & 0.415 & 0.071 & 5.875 & $* * *$ \\
Relatedness $\rightarrow$ Self-worth & 0.255 & 0.074 & 3.443 & $* * *$ \\
Self-worth $\rightarrow$ Playtime & 1.048 & 0.116 & 9.046 & $* * *$ \\
Self-worth $\rightarrow$ Satisfaction & 0.109 & 0.112 & 0.967 & 0.334 \\
Playtime $\rightarrow$ Satisfaction & 0.655 & 0.109 & 6.024 & $* * *$ \\
\hline
\end{tabular}

\begin{tabular}{|c|c|c|c|}
\hline \multicolumn{4}{|c|}{ TABLE V: MODEL FIT } \\
\hline $\begin{array}{l}\text { Goodness of Fit } \\
\text { Measurement }\end{array}$ & Estimates & $\begin{array}{c}\text { Cut- } \\
\text { off }\end{array}$ & Reference \\
\hline $\begin{array}{l}\text { Goodness of Fit Index } \\
\text { (GFI) }\end{array}$ & 0.86 & $>0.8$ & Gefen et al. (2000) \\
\hline Comparative of Fit Index & 0.92 & $>0.90$ & Hair (2010) \\
\hline$(\mathrm{CFI})$ & 0.82 & $>0.80$ & Gefen et al. (2000) \\
\hline
\end{tabular}

Adjusted Goodness of

Fit (AGFI)

Tucker Lewis Index $\quad 0.92 \quad>0.90 \quad \mathrm{Hu}$ and Bentler (1999)

(TLI)

Incremental Fit Index

(IFI)

Root Mean Square Error

of Approximation

Minimum Discrepancy

(CMIN/DF)

\section{DISCUSSION}

Based on the result shown in this study, the mobile legend players revealed that their playtime can be affected by their self-worth. The hypothesis that we formulate was accepted due to the fact that in the study of Liao and their group, they found out the if the player could feel their self-worth in the gameplay the tendency is that they would actively and repeatedly [10]. Also, our hypothesis the autonomy, competence, and relatedness that was positively related to self-worth was also accepted. From here, we can say applying the Self-Affirmation Theory (SAT) can also be used in assessing and determining the mobile gamers' playtime and satisfaction. Looking at the behavior of the mobile gamers particularly those who play Mobile Legends during this pandemic, they have more opportunity to play this game due to the lockdown implemented by the government. Since the pandemic may bring stress and strain with Gen Z-ers [18], [19], the study of Chen implies the mobile players tend to play more as part of their stress recovery purposes, and also the peer pressure can have a great impact to play more and be satisfied in the gameplay [10]. This previous study can be reflected in the results of autonomy, competence, and related which is positively related to self-worth. Surprisingly, the result of self-worth to satisfaction is not significantly related. According to our findings, the self-worth may not impact the satisfaction of an individual mobile gamer when playing a mobile game. The researchers think that since an individual has their own level of self-worth but their satisfaction in their game does not complement each other. The satisfaction may affect due to different circumstances like the internet connection, quality of the updated game, promos, gifts, avatar customization, etc.

The purpose of this study is to assess the playtime and satisfaction of mobile legend players during this pandemic. Using the principles of Self-Affirmation Theory with help of statistical analysis using the Structural Equation Modelling (SEM), this paper may contribute that SAT theory may also be applied in determining the behavior of the mobile game players.

However, this study is only limited particularly in the participants which the researchers gathered 257 players only and all of them are from the Philippines. The statistical analysis with the SEM was only assessed via factor analysis in which we test their factor loadings and their path coefficients as well as the model of fit test are presented in the result section. For future researchers, this paper may also be expanded to different parts of the places to increase the number of valid participants which will make it more reliable regarding this study. Also, since this paper is only limited to only one game, other researchers may add up more games that are also similar to the mode of game to make the analysis stronger.

\section{CONCLUSION}

From the results of this study, the researchers may imply that the playtime and satisfaction may also describe and explain using the Self-Affirmation (SAT) Theory. By verifying our model using the analysis of SEM, we can say 
that the model in describing the mobile legend player fits the data. The results also signify the factors which may affect the playtime and satisfaction of every mobile legend players during this pandemic. From previous studies, we can see the relations as we reflected it in our research. The self-worth has a great impact on the playtime as well as the playtime has a positive effect on satisfaction. By having this study, the researchers are hopefully contributed to the application of SAT theory with SEM by giving some additional insights into the behavior of mobile game players with this current health crisis.

\section{CONFLICT OF INTEREST}

The authors declare no conflict of interest.

\section{AUTHOR CONTRIBUTIONS}

RTK conducted the research, analyzed the data, and prepared the manuscript; YTP supervised; SFP and AANPR reviewed and edited the manuscript; all authors had approved the final version.

\section{ACKNOWLEDGMENT}

The authors would like to thank Mapúa University DRIVE for funding this study.

\section{REFERENCES}

[1] Y. T. Prasetyo, A. M. Castillio, L. J. Salonga, J. A. Sia, and J. A. Seneta, "Factors affecting perceived effectiveness of COVID-19 prevention measures among Filipinos during enhanced community quarantine in Luzon, Philippines: Integrating protection motivation theory and extended theory of planned behavior," International Journal of Infectious Diseases, vol. 99, pp. 312-323, October 2020.

[2] Department of Health. Updates on Novel Corona Virus Disease (COVID-19). [Online]. https://www.doh.gov.ph/2019-ncov/

[3] Pew Research Center. (May 14, 2020). Generation Z. [Online]. Available: https://www.pewresearch.org/topics/generation-z/

[4] G.-Y. Liao, T. T. L. Pham, T. C. E. Cheng, and C.-I. Teng, "How online gamers' participation fosters their team commitment: Perspective of social identity theory," International Journal of Information and Management, vol. 52, June 2020.

[5] FANDOM. Mobile Legends Bang Bang Wiki. [Online]. Available: https://mobile-legends.fandom.com/wiki/

[6] GAMERHUB. Mobile Legends Bang Bang Heroes. [Online]. Available: https://www.gamerhub.gg/mobile-legends-bang-bang/heroes/

[7] CNN Philippines, Philippines $201930^{\text {th }}$ Sea Games. [Online]. Available: https://cnnphilippines.com/seagames/

[8] C. M. Steele, "The psychology of self-affirmation: Sustaining the integrity of the self," Advances in Experimental Social Psychology, vol. 21, pp. 261-302, April 2008.

[9] M. L. Knowles, G. M. Lucas, D. C. Molden, W. L. Gardner, and K. K. Dean, "There's no substitute for belonging: Self-affirmation following social and nonsocial threats," Personality and Social Psychology Bulletin, vol. 36, no. 2, pp. 173-186.

[10] C. Cheng, "Playing mobile games for stress recovery purposes: A survey for Chinese adolescents," Telematics and Informatics, August 2020.

[11] Y. T. Prasetyo and D. G. D. D. Fuente, "Determinant factors affecting customer satisfaction among Filipinos in Lazada online shopping during COVID-19 pandemic: A structural equation modeling approach," presented at 20207 th International Conference on Frontiers of Industrial Engineering (ICFIE), 2020.

[12] J. P. Ramos and Y. T. Prasetyo, "The impact of work-home arrangement on the productivity of employees during COVID-19 pandemic in the Philippines: A structural equation modelling approach," presented at 2020 The 6th International Conference on Industrial and Business Engineering, 2020.
[13] G.-Y. Liao, T. T. L. Pham, T. Cheng, and C.-I. Teng, "Impacts of real-world need satisfaction on online gamer loyalty: Perspective of self-affirmation theory," Computers in Human Behavior, vol. 103, pp. 91-100, 2020.

[14] H. Kang and H. K. Kim, "My avatar and the affirmed self: Psychological and persuasive implications of avatar customization," Computers in Human Behavior, vol. 112, p. 106446, 2020.

[15] V. Barkoukis, R. Rowe, P. R. Harris, and L. Lazuras, "Self-affirmation effects on doping related cognition among exercisers who use nutritional supplements," Psychology of Sport and Exercise, vol. 46, p. 101609,2020

[16] F. Reer and N. C. Krämer, "A self-determination theory-based laboratory experiment on social aspects of playing multiplayer first-person shooter games," Entertainment Computing, vol. 34, p. 100353, 2020.

[17] V. Barkoukis, L. Lazuras, and P. R. Harris, "The effects of self-affirmation manipulation on decision making about doping use in elite athletes," Psychology of Sport and Exercise, vol. 16, pp. 175-181, 2015.

[18] X. Gong, C. Chen, and M. K. Lee, "What drives problematic online gaming? The role of IT identity, maladaptive cognitions, and maladaptive emotions," Computers in Human Behavior, vol. 110, p. 106386, 2020.

[19] C. L. Beard and R. E. Wickham, "Gaming-contingent self-worth, gaming motivation, and Internet Gaming Disorder," Computers in Human Behavior, vol. 61, pp. 507-515, 2016.

Copyright $\odot 2021$ by the authors. This is an open access article distributed under the Creative Commons Attribution License which permits unrestricted use, distribution, and reproduction in any medium, provided the original work is properly cited (CC BY 4.0).

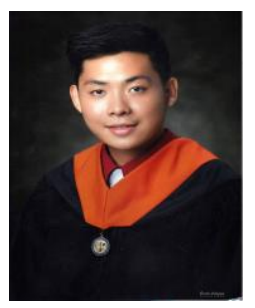

Ryuichi T. Kishimoto a registered electrical engineer. Currently he is a member of Faculty and Engineering Laboratory Custodian under the College of Engineering and Information Technology, Electrical Engineering Department. He received his degree in bachelor of science in electrical engineering from Pamantasan ng Lungsod ng Valenzuela (2016) having an awarded as dean's lister. He is now studying in Mapúa University taking up the master of science in engineering management (2019-present). In the field of electrical, he is interested in machineries and renewable energy. In the field of industrial, he is interested in production management, quality systems management (QMS), human factors / ergonomics and applied structural equation modelling (SEM). Apart from academics, Engr. Kishi likes singing, dancing and playing video games (PS4, Gamecube, Wii, etc.).

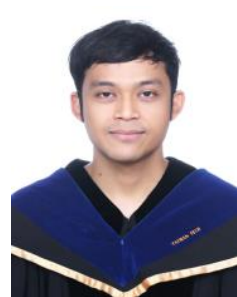

Yogi Tri Prasetyo is currently an associate professor in the School of Industrial Engineering and Engineering Management, Mapúa University, Philippines. He received a bachelor of engineering in industrial engineering from Universitas Indonesia (2013). He also studied for one year (2011-2012) at Waseda University, Japan, during his junior year as an undergraduate exchange student. He received an MBA (2015) and a Ph.D. (2019) from the Department of Industrial Management National Taiwan University of Science and Technology (NTUST), with a concentration in human factors and ergonomics. He was awarded as NTUST Outstanding Youth with a perfect GPA of 4.00. He has a wide range of research interests including human-computer interaction particularly related to eye movement, color optimization of military camouflage, strategic product design, usability analysis, and now he is currently doing accident analysis and prevention. He published several SCI journals in International Journal of Infectious Diseases, International Journal of Disaster Risk Reduction, Displays, Color Research and Application, Journal of Eye Movement Research, several non-SCI journals, and several conference proceedings. In addition, Dr.Yogi has contributed to several international conferences as co-chair, chair session, and even committee member with numerous best presentation awards. 


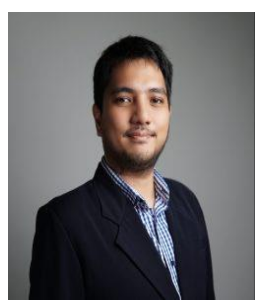

Satria Fadil Persada is a lecturer at the Business Management Department, Institut Teknologi Sepuluh Nopember (ITS), Surabaya, Indonesia. He received his bachelor degree from Information System Department, ITS. He continued his study and received his master and doctoral degree from Department of Industrial Management, National Taiwan University of Science and Technology (NTUST), Taipei, Taiwan. After completing his doctoral degree, he worked at Department of Business Management. Dr. Satria conducted a research on behavioral model, especially on psychological aspects that influence a person's intention when he was a doctor student at NTUST. Dr. Satria is now joining the Entrepreneurship and Small Medium Enterprsie (ESME) research lab in the Business Management Department. His research interest is studying the behavior of person's in the perspective of consumen and organizational. Dr. Satria' research interest is also related to pro environmental behavior.

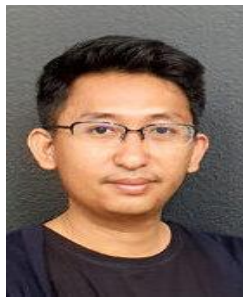

A. A. N. Perwira Redi is a lecturer in master of industrial engineering program at Bina Nusantara University, Indonesia. He achieved his doctoral degree at National Taiwan University of Science and Technology. He has many experiences in national and international research project related to logistics, supply chain, information system and many others. Dr. Perwira Redi has published in several SCI journals such as applied soft computing, computers $\&$ industrial engineering, computers \& operation research, expert systems with applications, and engineering optimization. 